\title{
Factors Affecting the Decision to Remain in the Hospitality Industry Among Hotel Front Office Desk Employees: The Case of Israel
}

\author{
Teitler Regev Sharon \\ Max Stern Academic College of Emek Yezreel, Galilee, Israel \\ Oksana Goziker \\ Kinneret College on the Sea of Galilee, Galilee, Israel \\ Shosh Shahrabani \\ Max Stern Academic College of Emek Yezreel, Galilee, Israel
}

\begin{abstract}
In the hotel industry, the front office serves as one of the most important points of contact with guests. One of the main problems in the hospitality industry is the high rate of turnover. This study examines skills and perceptions among front office employees in Israel, most of whom are young, single, and female. The study examines the main factors affecting an employee's intentions to remain in the hospitality industry. In addition, the study compares job perceptions and required skills between hotel chain and non-chain employees. The results suggest that being male, being an immigrant, and having a higher education raise intentions to remain in the hotel industry. Scoring higher on perceptions of the job increases an employee's intentions to remain in the industry as well. Higher position has a positive effect on the probability of remaining in the industry, while working for a chain does not affect this probability. In addition, this study attempts to offer front office managers some useful recommendations.
\end{abstract}

Keywords: human resources, skills, hotels, front office, Israel

\section{Introduction}

The tourism industry is one of the world's oldest industries. Today, the hotel industry generates $9 \%$ of the world's Gross Domestic Product (GDP) (World Travel and Tourism Council [WTTC], 2012) and almost 9\% of the world's employment (WTTC, 2012). Over the years, the industry has developed, and large hotel chains have introduced modern management and operation techniques to less developed countries. Despite these developments, the main resource in the hotel industry remains the human resource, and one of the main issues the hospitality industry must deal with is the high rate of turnover. International tourists, who usually come from developed nations, are very experienced and have certain expectations regarding the services they receive while traveling. In the hotel industry, the front office serves as one of the most important points of contact with the guests. Therefore, identifying the qualifications required of front office employees is very important.

Teitler Regev Sharon, Ph.D., lecturer, Department of Economics and Management, Max Stern Academic College of Emek Yezreel. Email: sharonregevt@gmail.com.

Oksana Goziker, lecturer, Department of Tourism and Hotel Studies, Kinneret College on the Sea of Galilee.

Shosh Shahrabani, professor, head of Department of Economics and Management, Max Stern Academic College of Emek Yezreel. 
Service industries in general and the hotel industry in particular are intangible industries. Therefore, customers evaluate their experience visiting hotels based on the tangible parts of an intangible product (the room, for example) and on the service they receive from hotel employees. The "service experience" takes place at the meeting point between employee and customer. The employees at that meeting point are known as contact employees in service industries and as front office employees in the hotel industry. These employees give their hotel a competitive advantage and differentiate it from other hotels (Pfeffer, 1994; Warhurst \& Nickson, 2007). In other words, front office employees play a significant role in building and maintaining a hotel's image and reputation. Hence, the skills and qualifications of front office employees have become very important.

The hotel industry is regarded as an industry that requires low-level skills and very little training (Crang, 1997; Shaw \& Williams, 1994; Westwood, 2002). For example, Baum and Odgers (2001) found no correlation between employees' education and the job they perform. They also found that hotels at all levels in Europe do not recruit new employees based on experience or specific traits (Baum \& Odgers, 2001). This view is sometimes debated in the literature (Witz, Warhurst, \& Nickson, 2003; Burns, 1997; Baum, 1996). The perception of the hotel industry as a low-skilled labor market may mean that many hotel and tourism organizations find it difficult to recruit more skilled employees in the open labor market, with the exception of large multinational organizations (Baum, 2008).

One of the biggest problems faced by the hotel industry is the high rate of turnover among hotel employees, which raises the economic costs of operating hotels. The difficulties experienced by the hospitality industry in attracting and retaining suitable employees are related to factors such as low pay, transient workforce, and a perceived or real lack of formal qualifications (Duncan, Scott, \& Baum, 2013). Tracey and Hinkin (2008) analyzed the cost of turnover and the factors influencing that cost. They found that the cost of turnover is higher for highly complex jobs, independent hotels, hotels with high average daily rates, larger hotels, and hotels with high occupancy. Ohlin and West (1993) studied the effect of different benefit plans on turnover rates in the housekeeping departments of 174 hotels in the southeast USA and found no statistically significant correlation between turnover rates and whether or not the hotel was part of a chain. Gunlu, Aksarayli, and Perçin (2010) studied managers in four- and five-star hotels in Turkey and found that managers of independent (non-chain) hotels had greater job satisfaction than managers of chain hotels. Greater job satisfaction may likely lead to lower turnover, though this study did not examine turnover rates.

Soni and Rawal (2014) also examined job satisfaction but not turnover rate at 120 hotels in Udaipur India and found no significant difference between employees at chain and non-chain hotels.

A great deal of research has focused on identifying the competencies needed by front office employees and front office managers in order to predict on-the-job success and help construct academic programs at hotel schools. Communication skills with guests and employees were found to be an important competency by many researchers (P. Jonker \& D. Jonker, 1990; Lin, 2002; Doyle, 1992; Crouch, 2004). Ashley, Bach, Chesser, Ellis, Ford, LeBruto, Milman, Pizam, and Quain (1995) found that other important skills included people skills, creative thinking ability, developing a service orientation, total quality management, problem identification and problem-solving skills, and listening skills.

Previous studies of hotel front office employees focused on identifying required competencies as well as on employees' perceptions about the jobs. Yet, to the best of our knowledge, no study has focused on the factors affecting employees' intentions of remaining in the hospitality industry and has not compared these intentions between employees at chain and non-chain hotels. 
Therefore, the objectives of the current study are: (1) to identify the factors affecting employees' intentions to remain in the hospitality industry; and (2) to compare levels of skills and perceptions between employees at chain and non-chain hotels.

The main study hypotheses are:

H1: Employees at chain hotels differ from those at non-chain hotels in their perceptions about their jobs and the skills required for the jobs.

H1 is based on the findings of Gunlu et al. (2010) and Soni and Rawal (2014), which pointed to higher satisfaction among chain hotel employees than among non-chain hotel employees. In addition, since attitudes affect intentions and willingness to remain in the industry, we hypothesize that:

H2: Employees' willingness to continue working in the hotel industry will be affected by whether or not they work at a chain hotel.

We also expect that socio-demographic factors will affect the willingness to remain in the industry. For example, previous research (Duncan et al., 2013) found that one of the reasons for high turnover is the lack of formal education. Thus, having a degree may decrease turnover and increase the likelihood an employee will remain in the industry.

The rest of the paper is as follows: Section 2 describes tourism in Israel; Section 3 describes the methodology; Section 4 describes the results; and Section 5 concludes.

\section{Tourism Industry in Israel}

Israel is holy to the three major religions (Islam, Christianity, and Judaism) and offers a wide range of opportunities for visitors, including historic cities such as Jerusalem and Acre, modern cities such as Tel Aviv, and sea resorts such as Eilat and the Dead Sea health resorts. Israel is located between Asia and Europe. Due to its location and the political situation between Israel and its neighbors, it can be reached either by air or by land crossing from Jordan or Egypt, but there is no easy access by train or by car from Europe (Israel Ministry of Tourism, 2013).

The tourism industry accounts for approximately $4 \%$ of the Israeli GDP and has become the third largest export industry in added value (Central Bureau of Statistics [CBS], 2012). Revenues from hotels in 2009 amounted to around $\$ 2$ billion, 40\% from tourists, and profits stood at \$368 million (CBS, 2012). In 2009, the Israeli hotel industry employed 26,000 people, 5,600 through outsourcing (CBS, 2012). The hotel industry in Israel includes 337 hotels with a total of 47,000 rooms, so that the average number of rooms per hotel is 142 . The average hotel occupancy rate is $66 \%$. The hotels vary from local chains to international chains to independent hotels. The number of hotel nights totaled over 22 million in 2010, and this figure is still growing (Israel Ministry of Tourism, 2013). Nevertheless, a shortage of hotel rooms is felt in the high season, especially in the Tel Aviv and Jerusalem areas, and thus further development in this sector is predicted (Israel Ministry of Tourism, 2013).

\section{Methodology}

\section{The Sample}

The sample included all hotels in Israel with 50 rooms or more. In each tourist area in Israel, 5-10 hotels were chosen representing individual hotels (e.g., not belonging to any chain), local chains, and international chains. In addition, these hotels represented different levels and types of hotels (business, recreation, luxury, and the like). The only condition for participating in this research was that at least $40 \%$ of the guests were international guests (analogous to the percentage of international guests in Israel) (CBS, 2012). 
Of the 260 hotels in Israel with 50 rooms or more, 70 (about 27\%) were approached to participate in the study. The hotels were sampled in a convenient sample based on availability of the front office staff to answer the questionnaire.

Out of the 70 hotels approached, about $46 \%$ (32 hotels) agreed to participate in the research. ${ }^{1}$ In the hotels comprising the sample, all front office employees were approached, with an average of about six employees at each hotel. The response rate at the hotels was $88 \%$. A total of 170 questionnaires were completed.

Employees' answers ${ }^{2}$ to the questionnaires indicated that on average, $48.57 \%$ of hotel guests are international guests. Of these, $45.82 \%$ arrive in groups. Of the hotels in the study, $58 \%$ were part of chains and $42 \%$ were individual hotels.

\section{Data Collection}

During February 2011, a pilot study was conducted at several hotels in Tiberias. The questionnaires were collected and analyzed, and at the end of April, the final questionnaire was distributed at various hotels. The researchers contacted the hotel managers by email and phone. After receiving a letter indicating the manager's agreement to participate in the research, the research assistant sent the questionnaires to the hotel front office by the chosen method (mail, email, or fax). The questionnaires were completed by front office employees at all levels: front office managers, supervisors, and desk clerks. The completed questionnaires were returned by mail. If a hotel manager failed to return the completed questionnaire after about eight weeks after agreeing to participate, the research assistant would personally visit the hotel, bringing the questionnaires to be filled in. Since front office employees work in shifts, not all of them were present during the research assistant's visit.

Since at many hotels working in the front office is a seasonal job and since the intention was to examine employees during all seasons, this process was repeated in October at hotels from the same sample that had not been approached the first time around.

\section{The Research Tool}

The research questionnaire was partially based on the questionnaire developed by Kong and Baum (2006), and its final version was decided upon after analyzing data from a pilot questionnaire distributed at several hotels in one area.

The questionnaire consisted of the following parts: (1) items requesting socio-demographic information, including age, marital status, education, previous experience, future plans, and current position; (2) questions about the hotel, including whether it caters to international tourists and groups; ${ }^{3}$ and (3) questions concerning perceptions about working in the front office, such as "Which part of the job do you enjoy the most?", questions regarding how the employee's family and friends perceive the job, whether it requires prior experience or education, and questions with respect to the required skills. These questions were measured on a 5-point scale ranging from 1 (“certainly do not agree”) to 5 (“certainly agree”). The last part of the questionnaire was based on the tested and retested Kong and Baum's (2006) questionnaire. Finally, the internal consistency reliability (Cronbach's alpha) was checked and found to be higher than 0.70 ( 0.744 for worker perception and 0.786 for required skills). The scores on each of the scales were averaged to create independent variables.

\footnotetext{
${ }^{1}$ No apparent differences in employee demographics were found between hotels whose mangers agreed to participate in the research and those whose managers did not agree.

2 Employees' answers may be based on perceptions instead of on actual knowledge.

3 Since we did not find any significant difference among hotels with respect to this question, we did not include it in our results.
} 


\section{Data Analysis}

The Statistical Package for Social Sciences (SPSS) 17 was used to conduct the statistical analysis of the data. The current research used the following techniques: Spearman correlation and Chi-square test to test the correlation between two variables, independent sample $T$-test to compare among groups, and logistic binary regression to predict the probability that a front office employee will continue to work in the hotel industry or leave it.

\section{Results}

\section{Descriptive Statistics}

The sample included 90 employees (54.2\%) who work in hotels that are part of a chain and 76 employees (45.8\%) who work in non-chain hotels.

The demographic information on the hotel employees in Israel is summarized in Table 1.

Table 1

Demographic Data for the Sample

\begin{tabular}{|c|c|c|c|c|}
\hline \multirow{2}{*}{ Variable } & \multirow{2}{*}{ Category } & \multicolumn{3}{|c|}{ Is the hotel part of a chain? } \\
\hline & & Yes & No & Total \\
\hline \multirow{2}{*}{ Origin } & Native Israeli & $\begin{array}{c}63 \\
(73.3 \%) \\
\end{array}$ & $\begin{array}{l}58 \\
(78.4 \%) \\
\end{array}$ & $\begin{array}{l}121 \\
(75.63 \%)\end{array}$ \\
\hline & Immigrant & $\begin{array}{l}23 \\
(26.7 \%) \\
\end{array}$ & $\begin{array}{c}16 \\
(21.6 \%) \\
\end{array}$ & $\begin{array}{c}39 \\
(24.37 \%) \\
\end{array}$ \\
\hline \multirow{2}{*}{ Gender } & Male & $\begin{array}{c}34 \\
(39.5 \%) \\
\end{array}$ & $\begin{array}{c}23 \\
(31.1 \%) \\
\end{array}$ & $\begin{array}{c}57 \\
(35.63 \%) \\
\end{array}$ \\
\hline & Female & $\begin{array}{c}52 \\
(60.5 \%)\end{array}$ & $\begin{array}{c}51 \\
(68.9 \%)\end{array}$ & $\begin{array}{l}103 \\
\text { (64.37\%) }\end{array}$ \\
\hline \multirow{2}{*}{ Marital status } & Married & $\begin{array}{l}23 \\
(25.6 \%) \\
\end{array}$ & $\begin{array}{c}17 \\
(22.4 \%) \\
\end{array}$ & $\begin{array}{l}40 \\
(24.10 \%)\end{array}$ \\
\hline & Not married & $\begin{array}{c}67 \\
(74.4 \%) \\
\end{array}$ & $\begin{array}{c}59 \\
(77.6 \%) \\
\end{array}$ & $\begin{array}{l}126 \\
(75.90 \%)\end{array}$ \\
\hline \multirow{3}{*}{ Education } & High school & $\begin{array}{c}37 \\
(43.5 \%)\end{array}$ & $\begin{array}{c}35 \\
(47.3 \%)\end{array}$ & $\begin{array}{c}72 \\
(45.28 \%)\end{array}$ \\
\hline & Professional & $\begin{array}{c}15 \\
(17.7 \%) \\
\end{array}$ & $\begin{array}{c}12 \\
(16.2 \%)\end{array}$ & $\begin{array}{l}27 \\
(16.98 \%) \\
\end{array}$ \\
\hline & Academic degree & $\begin{array}{c}33 \\
(38.8 \%)\end{array}$ & $\begin{array}{l}27 \\
(36.5 \%) \\
\end{array}$ & $\begin{array}{c}60 \\
(37.74 \%) \\
\end{array}$ \\
\hline
\end{tabular}

Table 1 reveals that the distribution of the demographic data is similar among those who work in hotels that are part of a chain and those who work at non-chain hotels. For example, the majority of the front office employees are women in both the chain and non-chain hotels (60.5\% and 68.9\%, respectively). In addition, $73.3 \%$ of those who work in chain hotels and $78.4 \%$ of those who work in non-chain hotels were born in Israel.

The findings (not shown in Table 1 ) also reveal that the majority of respondents $(66.2 \%: 68.9 \%$ of chain hotel workers and $63.2 \%$ of non-chain hotel workers) speak more than one foreign language, 30.7\% speak only one foreign language (30\% of chain workers and $31.6 \%$ of non-chain workers), and $3 \%$ speak only Hebrew (1.1\% and 5.3\%, respectively). Among the foreign languages are English, Russian, Turkish, Arabic, Yiddish, and German.

Table 2 summarizes the respondents’ employment history and future plans. 
Table 2

Respondents' Employment History and Future Plans

\begin{tabular}{|c|c|c|c|c|c|}
\hline \multirow{2}{*}{ Variable } & \multirow{2}{*}{ Category } & \multicolumn{3}{|c|}{ Is the hotel part of a chain? } & \multirow{2}{*}{$-X^{2}$} \\
\hline & & Yes & No & Total & \\
\hline \multirow{3}{*}{$\begin{array}{l}\text { Time at current } \\
\text { position }\end{array}$} & Less than one year & $\begin{array}{c}35 \\
(40.2 \%) \\
\end{array}$ & $\begin{array}{c}34 \\
(46.5 \%) \\
\end{array}$ & $\begin{array}{l}69 \\
(43.13 \%) \\
\end{array}$ & \multirow{3}{*}{2.489} \\
\hline & Between one and five years & $\begin{array}{l}40 \\
(46 \%)\end{array}$ & $\begin{array}{c}31 \\
(42.5 \%) \\
\end{array}$ & $\begin{array}{l}71 \\
(44.37 \%) \\
\end{array}$ & \\
\hline & More than five years & $\begin{array}{c}12 \\
(13.8 \%)\end{array}$ & $\begin{array}{c}8 \\
(11 \%) \\
\end{array}$ & $\begin{array}{l}20 \\
(12.50 \%)\end{array}$ & \\
\hline \multirow{3}{*}{$\begin{array}{l}\text { Time at current } \\
\text { chain }\end{array}$} & Less than one year & $\begin{array}{l}29 \\
(39.2 \%) \\
\end{array}$ & $\begin{array}{c}27 \\
(60 \%) \\
\end{array}$ & $\begin{array}{l}56 \\
(47.06 \%) \\
\end{array}$ & \multirow{3}{*}{$8.719^{*}$} \\
\hline & Between one and five years & $\begin{array}{c}35 \\
(47.3 \%) \\
\end{array}$ & $\begin{array}{c}15 \\
(33.3 \%) \\
\end{array}$ & $\begin{array}{l}50 \\
(42.02 \%) \\
\end{array}$ & \\
\hline & More than five years & $\begin{array}{c}10 \\
(13.5 \%)\end{array}$ & $\begin{array}{c}3 \\
(6.7 \%)\end{array}$ & $\begin{array}{l}13 \\
(10.92 \%)\end{array}$ & \\
\hline \multirow{5}{*}{ Next career move } & Promotion in my current job & $\begin{array}{l}35 \\
(42.7 \%) \\
\end{array}$ & $\begin{array}{l}13 \\
(19.4 \%) \\
\end{array}$ & $\begin{array}{l}48 \\
(32.21 \%)\end{array}$ & \multirow{5}{*}{$20.813^{* * *}$} \\
\hline & Move elsewhere in this hotel & $\begin{array}{l}6 \\
(7.3 \%)\end{array}$ & $\begin{array}{c}1 \\
(1.5 \%)\end{array}$ & $\begin{array}{l}7 \\
(4.70 \%)\end{array}$ & \\
\hline & Move to another hotel & $\begin{array}{l}1 \\
(1.2 \%)\end{array}$ & $\begin{array}{l}11 \\
(16.4 \%)\end{array}$ & $\begin{array}{l}12 \\
(8.05 \%)\end{array}$ & \\
\hline & Move out of the hotel sector & $\begin{array}{l}25 \\
(30.5 \%) \\
\end{array}$ & $\begin{array}{c}25 \\
(37.3 \%) \\
\end{array}$ & $\begin{array}{l}50 \\
(33.56 \%) \\
\end{array}$ & \\
\hline & Other & $\begin{array}{c}15 \\
(18.3 \%)\end{array}$ & $\begin{array}{c}17 \\
(25.4 \%)\end{array}$ & $\begin{array}{l}32 \\
(21.48 \%)\end{array}$ & \\
\hline \multirow{4}{*}{$\begin{array}{l}\text { Perception of } \\
\text { chances for } \\
\text { promotion }\end{array}$} & Excellent & $\begin{array}{l}19 \\
(22.1 \%) \\
\end{array}$ & $\begin{array}{c}4 \\
(5.3 \%) \\
\end{array}$ & $\begin{array}{l}23 \\
(14.29 \%)\end{array}$ & \multirow{4}{*}{$-12.5926^{* *}$} \\
\hline & Reasonable & $\begin{array}{c}21 \\
(24.4 \%) \\
\end{array}$ & $\begin{array}{l}13 \\
(17.3 \%)\end{array}$ & $\begin{array}{l}34 \\
(21.12 \%)\end{array}$ & \\
\hline & Low & $\begin{array}{l}28 \\
(32.6 \%) \\
\end{array}$ & $\begin{array}{c}38 \\
(50.7 \%) \\
\end{array}$ & $\begin{array}{l}66 \\
(40.99 \%) \\
\end{array}$ & \\
\hline & Unable to evaluate & $\begin{array}{c}18 \\
(20.9 \%)\end{array}$ & $\begin{array}{c}20 \\
(26.7 \%)\end{array}$ & $\begin{array}{l}38 \\
(23.60 \%)\end{array}$ & \\
\hline
\end{tabular}

Notes. 1 = Do not agree at all, 5 = Very much agree. ${ }^{*}: p<0.05 ;{ }^{* * *}: p<0.01 ;$ and ${ }^{* * *}: p<0.001$.

A Chi-square test was conducted to test the correlation between "Does the respondent work at a chain?" and the time the respondent has worked at the current chain. A moderate and statistically significant correlation was found between the variables $\left(X^{2}(2)=8.719, \mathrm{C}=0.271, p<0.05\right)$. Among those working at chains, the majority (approximately 60\%) have been working more than one year, compared to $40 \%$ of those who work at non-chain hotels.

A Chi-square test was conducted also to test the correlation between "Does the respondent work at a chain?" and the respondent's "next career move”. A statistically significant correlation was found among the variables $(p<0.05)$. Of those who work at a chain hotel, $51.2 \%$ plan to continue working in the hospitality industry, as do about $37.3 \%$ of those who work at a non-chain hotel.

This result, which is in line with H2, may be related to the fact that the majority of non-chain employees estimated their chances of promotion at the hotel as low (50.7\%), compared to a lesser percent (32.6\%) of chain hotel employees who estimated low chances of promotion. In addition, only $19.4 \%$ of non-chain employees estimated that they would be promoted in their current jobs, compared to $42.7 \%$ of those from chain hotels.

Table 2 also reveals a moderate and statistically significant correlation between the variables "Does the respondent work at a chain?" and "possibility of being promoted" $(p<0.05)$. Among those who work at a chain 
hotel, $46.5 \%$ think that they have a good or excellent probability of being promoted, while only $22.6 \%$ of non-chain hotel employees think that they have good or excellent chances of promotion.

We also found a positive significant correlation between employees’ position and their education level (Rs $=0.290, p<0.0001)$.

\section{Employees' Perceptions}

The questions relating to employees' perceptions of their jobs included several statements. Front office employees were asked to rate their levels of agreement with these statements on a 5-point Likert scale, ranging from 1 ("do not agree") to 5 ("very much agree"). The individual results were then averaged to obtain the average perception. Table 3 presents the mean values of the perceptions of employees from chain and non-chain hotels.

Table 3

\section{Perceptions About the Job}

\begin{tabular}{|c|c|c|c|c|}
\hline Perception & $\begin{array}{l}\text { Is the hotel part of a } \\
\text { chain? }\end{array}$ & $N$ & $\begin{array}{l}\text { Mean response on a } \\
\text { 5-point scale }\end{array}$ & $\begin{array}{l}\text { Standard } \\
\text { deviation }\end{array}$ \\
\hline \multirow{2}{*}{ Front office work is all about personality } & Yes & 90 & 4.43 & 0.654 \\
\hline & No & 76 & 4.36 & 0.934 \\
\hline \multirow{2}{*}{ I enjoy meeting and greeting customers as part of my job } & Yes & 90 & 4.24 & 0.783 \\
\hline & No & 75 & 3.99 & 0.951 \\
\hline \multirow{2}{*}{$\begin{array}{l}\text { A special college course (on hotel work) is useful for front } \\
\text { office work }\end{array}$} & Yes & 87 & 4.17 & 0.865 \\
\hline & No & 70 & 3.88 & 1.119 \\
\hline \multirow{2}{*}{$\begin{array}{l}\text { Front office work is a challenging and demanding area of } \\
\text { work }\end{array}$} & Yes & 89 & 4.09 & 0.874 \\
\hline & No & 75 & 3.88 & 1.115 \\
\hline \multirow{2}{*}{ Most of the front office work is common sense } & Yes & 88 & 3.99 & 0.941 \\
\hline & No & 75 & 3.8 & 1.027 \\
\hline \multirow{2}{*}{ My area of work is well respected by my family and friends } & Yes & 90 & 3.93 & 0.897 \\
\hline & No & 76 & 3.71 & 1.056 \\
\hline \multirow{2}{*}{ I enjoy the organizational parts of my job } & Yes & 88 & $3.91^{* *}$ & 0.947 \\
\hline & No & 76 & 3.43 & 1.159 \\
\hline \multirow{2}{*}{ I enjoy the use of technology as part of my job } & Yes & 90 & 3.59 & 1.111 \\
\hline & No & 76 & 3.34 & 1.15 \\
\hline \multirow{2}{*}{$\begin{array}{l}\text { I was familiar with most of the tasks of the front office } \\
\text { before I started working in this area }\end{array}$} & Yes & 90 & 3.41 & 1.445 \\
\hline & No & 76 & 3.11 & 1.42 \\
\hline \multirow{2}{*}{$\begin{array}{l}\text { I would like the opportunity to work in other areas of the } \\
\text { hotel industry }\end{array}$} & Yes & 88 & 3.13 & 1.388 \\
\hline & No & 74 & 3.04 & 1.466 \\
\hline \multirow{2}{*}{$\begin{array}{l}\text { The front office is my preferred field for work and career } \\
\text { advancement }\end{array}$} & Yes & 89 & $3.01^{*}$ & 1.369 \\
\hline & No & 75 & 2.55 & 1.369 \\
\hline
\end{tabular}

Notes. 1 = Do not agree at all, 5 = Very much agree. ${ }^{*}: p<0.05 ;{ }^{* *}: p<0.01$; and ${ }^{* * * *}: p<0.001$.

The results show that respondents from both chain and non-chain hotels strongly agreed with the following statements: "Front office work is all about personality", "I enjoy meeting and greeting customers as part of my job”, and "A special college course (on hotel work) is useful for front office work".

Yet, we found significant differences between chain and non-chain employees with respect to the following two items: "I enjoy the organizational parts of my job" (3.91 for chain employees versus 3.43 for non-chain employees, $p<0.01$ ) and "Front office is my preferred field for work and career advancement" (3.01 for chain employees versus 2.55 for non-chain employees, $p<0.05$ ). This supports H1. The last correlation may suggest that front office employees in chain hotels prefer to work and advance in this job more than do front office employees in non-chain hotels, in line with H2. 


\section{Required Skills}

Table 4 summarizes the mean values and standard deviations of chain and non-chain hotel employees' perceptions regarding the importance of skills required in the front office position. The employees were asked to rate their levels of agreement with the statements on a 5-point Likert scale ranging from 1 ("do not agree”) to 5 ("very much agree"). The individual results were averaged to reach the average perception.

Table 4

Employees' Perceptions Regarding the Importance of Skills for Their Jobs

\begin{tabular}{|c|c|c|c|c|}
\hline Skill required for employees’ jobs & $\begin{array}{l}\text { Is the hotel part } \\
\text { of a chain? }\end{array}$ & $N$ & $\begin{array}{l}\text { Mean response on } \\
\text { a 5-point scale }\end{array}$ & Standard deviation \\
\hline \multirow{2}{*}{ Customer care } & Yes & 87 & 4.80 & 0.478 \\
\hline & No & 76 & 4.76 & 0.563 \\
\hline \multirow{2}{*}{ Communication (oral) } & Yes & 88 & 4.77 & 0.707 \\
\hline & No & 76 & 4.62 & 0.653 \\
\hline \multirow{2}{*}{ Knowledge of foreign language(s) } & Yes & 88 & 4.74 & 0.577 \\
\hline & No & 76 & 4.59 & 0.769 \\
\hline \multirow{2}{*}{ Interpersonal skills } & Yes & 88 & 4.69 & 0.748 \\
\hline & No & 76 & 4.63 & 0.65 \\
\hline \multirow{2}{*}{ Teamwork } & Yes & 87 & $4.67^{* *}$ & 0.604 \\
\hline & No & 76 & 4.41 & 0.866 \\
\hline \multirow{2}{*}{ Professional and ethical standards } & Yes & 86 & 4.62 & 0.654 \\
\hline & No & 76 & 4.51 & 0.721 \\
\hline \multirow{2}{*}{ Use of front office equipment } & Yes & 86 & $4.24^{* *}$ & 0.894 \\
\hline & No & 76 & 3.80 & 1.166 \\
\hline \multirow{2}{*}{ Leadership qualities } & Yes & 86 & $4.13^{* *}$ & 0.895 \\
\hline & No & 76 & 3.60 & 1.188 \\
\hline \multirow{2}{*}{ Communication (written) } & Yes & 87 & $3.97^{* *}$ & 0.892 \\
\hline & No & 76 & 3.59 & 1.191 \\
\hline \multirow{2}{*}{ Use of technology } & Yes & 88 & $3.72^{*}$ & 1.122 \\
\hline & No & 76 & 3.08 & 1.205 \\
\hline \multirow{2}{*}{ Health and safety } & Yes & 88 & $3.73^{* * *}$ & 1.122 \\
\hline & No & 76 & 3.33 & 1.182 \\
\hline \multirow{2}{*}{ Marketing } & Yes & 88 & 3.53 & 1.103 \\
\hline & No & 76 & 3.34 & 1.172 \\
\hline \multirow{2}{*}{ Accounting } & Yes & 87 & $3.45^{* *}$ & 1.198 \\
\hline & No & 75 & 2.87 & 1.143 \\
\hline \multirow{2}{*}{ Legal issues } & Yes & 88 & $2.92^{* *}$ & 1.252 \\
\hline & No & 75 & 2.32 & 1.176 \\
\hline
\end{tabular}

Notes. 1 = Do not agree at all, 5 = Very much agree. ${ }^{*}: p<0.05 ;{ }^{* * *}: p<0.01$; and ${ }^{* * * *}: p<0.001$.

These results shown in Table 4 indicate that the following skills were considered to be the most important for employees, in both chain and non-chain hotels: customer care, followed by communication (oral), knowledge of foreign language(s), interpersonal skills, teamwork, and professional and ethical standards. The employees perceived legal issues to be the least important skill. Accounting, marketing, and health and safety were also perceived as less important, though significantly more important than legal issues. 
The table reveals significant differences between employees of chain and non-chain hotels regarding their perceptions of teamwork, use of front office equipment, leadership qualities, communication, use of technology, health and safety, legal issues, and accounting, in line with H1. It is important to mention that in all cases, the perceived importance of required skills was higher among employees of chain hotels than among employees of hotels that are not part of a chain.

\section{Analytical Model: Logistic Regression}

A logistic regression analysis was conducted to predict employees' intentions to remain in the hotel industry. The dependent variable was "next career move" in two categories: intention to stay in the industry and intention to leave the industry. The independent variables included gender, a dummy variable for whether or not the hotel belonged to a chain, previous experience, country of origin, perceptions about front office work and required skills (both an average of different skills and perceptions), and career promotion possibilities (on a scale ranging from 1 to 5 , where 5 = high chances and $1=$ low chances).

Table 5

Logistic Regression for Intention to Leave the Hotel Industry

\begin{tabular}{lllllc}
\hline & Variable & B & S.E. & Sig. & Exp (B) \\
\hline & Gender (male) & 1.196 & 0.483 & 0.013 & 3.306 \\
& Country of origin & -1.048 & 0.496 & 0.035 & 0.350 \\
(Base = born in Israel) & & & & 0.000 & 12.779 \\
& Perceptions about front office work & 2.548 & 0.566 & 0.207 & 0.514 \\
Step 1 & Perceptions about required skills & -0.666 & 0.528 & 0.032 & 0.359 \\
& Education level & -1.024 & 0.477 & 0.489 & 0.855 \\
& (Base = not highly educated) & & & 0.854 & 0.086 \\
& Possibility of promotion & -0.156 & 0.226 & & 0.004 \\
\hline
\end{tabular}

Note. $N=170\left(\chi^{2}(\mathrm{df}=7)=46.522, p<0.000\right)$.

The regression model was found to be statistically significant. Predictor variables (Nagelkerke $R^{2}$ ) explain $38.5 \%$ of the variance in the dependent variable, which represents the median relationship between prediction and grouping. The prediction's overall success was $75.2 \%$ (81.6\% for "intend not to continue working at the hotel" and $67.2 \%$ for "intend to continue working at the hotel").

The findings of Table 5 also indicated that male gender results in a $3.306(p<0.013)$ times greater likelihood that a respondent will continue to work at the hotel. The fact that an employee was born in Israel reduces the likelihood of remaining in the industry by $0.350(p<0.035)$. In addition, a one-point increase in the average perception regarding front office work results in a 12.779 times greater likelihood of continuing to work at the hotel $(p<0.0001)$, while less education decreases this likelihood by a factor of $0.359(p<0.032)$. Previous experience, career promotion possibilities, perceptions about required skills, and working at a chain hotel were not found to be statistically significant. ${ }^{4}$

In a different regression (not shown here), we found that working at a chain hotel significantly increases the likelihood that employees will perceive their chances of promotion as good.

\footnotetext{
${ }^{4}$ Education included two levels: higher education and other. Using a different distribution of high school and above did not change the results. In addition, adding age or marital status did not change the results.
} 


\section{Discussion and Conclusions}

The current study examines the factors affecting the intentions of front office employees working at both chain and non-chain hotels to remain in the hotel industry and reveals their perceptions with respect to their jobs and required skills.

The results of the study indicate that in Israel, the majority of hotel front office employees are young (average age of 29.11), single, and female. In addition, almost 34\% of hotel employees do not intend to remain in the hotel industry in the future. As for perceptions of front office work, the results show a high level of agreement between both chain and non-chain hotel employees with respect to almost all items, and in particular, for the items "Front office work is all about personality”, "I enjoy meeting and greeting customers as part of my job”, and "A specialist college course (on hotel work) is useful for front office work".

Nevertheless, our results also indicate that the perceived importance was higher among employees of chain hotels than among employees of hotels that are not part of a chain with respect to the following items: "I enjoy the organizational parts of my job” and "Front office is my preferred field for work and career advancement”.

In addition, the perceived importance of skills required for front office work was significantly higher among employees of chain hotels than among employees of hotels that are not part of a chain. These skills include teamwork, use of front office equipment, leadership qualities, communication, use of technology, health and safety, legal issues, and accounting.

One possible explanation for the differences in perceptions between chain and non-chain employees could be the size of the hotel. Chain hotels are usually larger than non-chain hotels, which may affect employees' perceptions with respect to needed skills and their general perceptions with respect to their chances of career advancement and even their job satisfaction.

The regression results show no correlation between the likelihood of remaining in the hospitality industry and being part of a chain. This is in line with an earlier finding in the literature (Ohlin \& West, 1993).

The regression results show that having an academic degree increases the likelihood of remaining in the hotel industry. This finding supports H2 and is in line with previous research (Duncan et al., 2013) which found that lack of education increases the rate of turnover.

The analytical model results indicate that perceiving the job as more important increases the intention to remain in the industry. Yet, we did not find any significant effect of working at a chain hotel on the intention to remain in the industry. This result is compatible with the finding of Ohlin and West (1993) that turnover rate is not significant with respect to the housekeeping workers at chain and non-chain hotels.

Our results also show that male gender, immigrant status, and higher education increase the intention to remain in the hotel industry. However, previous experience does not have any significant effect on the intention to remain in the industry.

\section{Implications}

Based on the results of the study, the following recommendations can be made:

(1) Since employees' perceptions with respect to their jobs directly affect their intentions to remain in or leave the hotel industry, decision-makers in the hotel industry should take steps to improve employees' perceptions and job satisfaction (for example, providing special training courses for front office employees and opportunities for career advancement); 
(2) Managers who would like to lower the turnover rate should hire employees with higher education for front office jobs, as this may increase their intentions to remain in the industry;

(3) Women are less likely to remain in the hotel industry. Therefore, hotel managers should find ways to encourage women to remain in the hotel industry (e.g., special arrangements for working mothers);

(4) Israel is a country that has absorbed large waves of immigration from the former Union of Soviet Socialist Republics (USSR) since the 1990s. The results indicate that immigrants are more likely to remain in the industry (perhaps because of their knowledge of languages). Therefore, hotel managers should hire immigrants to lower the turnover rate, and the government should recognize that the hotel industry can serve as a tool to facilitate the absorption of immigrants in Israel.

\section{References}

Ashley, R. A., Bach, S. A., Chesser, J. W., Ellis, E. T., Ford, R. C., LeBruto, S. M., Milman, A., Pizam, A., \& Quain, W. J. (1995). A customer based approach to hospitality education. The Cornell Hotel and Restaurant Administration Quarterly, 36(4), 74-79.

Baum, T. (1996). Unskilled work and the hospitality industry: Myth or reality? International Journal of Hospitality Management, 15(3), 207-209.

Baum, T. (2008). Implications of hospitality and tourism labour markets for talent management strategies. International Journal of Contemporary Hospitality Management, 20(7), 720-729.

Baum, T., \& Odgers, P. (2001). Benchmarking best practice in hotel front office: The Western European experience. Journal of Quality Assurance in Hospitality and Tourism, 2(3-4), 93-109.

Burns, P. M. (1997). Hard-skills, soft-skills: Undervaluing hospitality's 'service with a smile'. Progress in Tourism and Hospitality Research, 3(3), 239-248.

Central Bureau of Statistics [CBS]. (2012). Tourism and hospitality services 2000-2012. Retrieved from http://www.cbs.gov.il/reader/cw_usr_view_SHTML?ID=336

Crang, P. (1997). Performing the tourist product. In C. Rojek, \& J. Urry (Eds.), Touring cultures: Transformations of travel and theory (pp. 137-154). London: Routledge.

Crouch, C. (2004). Skill formation systems. In S. Ackroyd, R. Batt, P. Thompson, \& P. S. Tolbert (Eds.), The Oxford handbook of work and organization (pp. 95-114). Oxford: Oxford University Press.

Doyle, K. (1992). Mastering motivation. Incentive, 166(3), 20-23.

Duncan, T., Scott, D. G., \& Baum, T. (2013). The mobilities of hospitality work: An exploration of issues and debates. Annals of Tourism Research, 41, 1-19.

Gunlu, E., Aksarayli, M., \& Perçin, N. S. (2010). Job satisfaction and organizational commitment of hotel managers in Turkey. International Journal of Contemporary Hospitality Management, 22(5), 693-717.

Israel Ministry of Tourism. (2013). Geography \& nature in Israel. Retrieved from http://goisrael.com/Tourism_Eng/Tourist\%20Information/Discover\%20Israel/Pages/Geography\%20and\%20Nature.aspx

Jonker, P., \& Jonker, D. (1990). What do hospitality graduates really need? An industry perspective. Hospitality and Tourism Educator, 3(1), 12-13.

Kong, H. Y., \& Baum, T. (2006). Skills and work in the hospitality sector: The case of hotel front office employees in China. International Journal of Contemporary Hospitality Management, 18(6), 509-518.

Lin, S. C. (2002). Exploring the relationships between hotel management courses and industry required competencies. Journal of Teaching in Travel and Tourism, 2(3-4), 81-101.

Ohlin, J. B., \& West, J. J. (1993). An analysis of the effect of fringe benefit offerings on the turnover of hourly housekeeping workers in the hotel industry. International Journal of Hospitality Management, 12(4), 323-336.

Pfeffer, J. (1994). Competitive advantage through people: Unleashing the power of the work force. Boston: Harvard Business School Press.

Shaw, G., \& Williams, A. (1994). Critical issues in tourism: A geographical perspective. Oxford: Blackwell.

Soni, H., \& Rawal, Y. S. (2014). Impact of quality of work life on employee satisfaction in hotel industry. IOSR Journal of Business and Management, 16(3), 37-44. 
Tracey, J. B., \& Hinkin, T. R. (2008). Contextual factors and cost profiles associated with employee turnover. Cornell Hospitality Quarterly, 49(1), 12-27.

Warhurst, C., \& Nickson, D. (2007). Employee experience of aesthetic labour in retail and hospitality. Work, Employment, and Society, 21(1), 103-120.

Westwood, A. (2002). Is new work good work? London: The Work Foundation.

Witz, A., Warhurst, C., \& Nickson, D. (2003). The labour of aesthetics and the aesthetics of organization. Organization, 10(1), 33-54.

World Travel and Tourism Council [WTTC]. (2012). Travel and tourism economic impact. Retrieved from http://www.google.co.il/url?sa=t\&rct=j\&q=\&esrc=s\&frm=1\&source=web\&cd=1\&ved=0CBwQFjAA\&url=http\%3A\%2F\%2 Fwww.wttc.org\%2F \%2Fmedia\%2Ffiles\%2Freports\%2Feconomic\%2520impact\%2520research\%2Fregional\%2520reports \%2Fworld2014.ashx\&ei=0gmVVL3KMsWHPbeQgYAB\&usg=AFQjCNFw0VVjx0rC40ZNO-h62yEv7G75qQ\&sig2=3avtk b_3TgYMyqR93Gi03Q\&bvm=bv.82001339,d.d2s 